\title{
The Challenges of Evolving and Developing
}

\section{Management Indigenous Theories and Practices in Africa}

\author{
Benjamin James Inyang \\ Department of Business Management, University of Calabar P.M.B. 1115 Calabar, Nigeria \\ E-mail: benji1955.unical@yahoo.co.uk
}

\begin{abstract}
The evolution and development of indigenous management theories and practices in Africa has been seriously affected and retarded by colonialism. The colonial administration introduced western management theories and practices, considered as the drivers and the panacea for the continent's socio-politico-economic development. Western scholarship and literature generally devalued and deprecated the astonishing management prowess and practices of early African civilizations, as evidenced, for example, in the building of the great Egyptian pyramids. These foreign management systems generally failed to achieve the expected goals as they discountenanced African cultural inertia and social milieu. The paper argued for the development of indigenous African management philosophy, which will be rooted in the African culture, value system and beliefs, to provide the practical way for the efficient and effective running of organizations in Africa, with its global competitiveness. The Ubuntu management system and the "new management techniques", which emphasize humanness, communalism and African patriotism, provide the veritable starting point for the development of indigenous African management philosophy.
\end{abstract}

Keywords: African management philosophy, Ubuntu, New management techniques, Management theories, Management practices, Management principles

\section{Introduction}

Scholarly conceptualization from Europe and the United States of America concerning management in Africa have tended to disparage its development, creating a binary management systems of "developed" western management theories and concepts and "underdeveloped" African management thoughts. Western management literature stridently emphasizes this dichotomy, with unabated importation of western management theories and practices to Africa at the detriment of developing indigenous African management theories, which will accommodate the continent's cultural inertia. Gbadamosi (2003) aptly notes that:

"Western management concepts and writings have dominated the thinking of academics and managers in Africa for a long-time. Such writings have not shown how culture might be taken into account in managerial practice" (pp. 274).

There in no doubt that "management in Africa is strongly rooted in cultural beliefs and traditions" (Fashoyin, 2005, pp. 43). The arrival of colonialism in Africa in the $19^{\text {th }}$ century disrupted the people's cultural beliefs and traditions, and thus "triggered the beginning of what may be called "colonized African management" according to (Eze, 1995, pp. 136-137). The colonial regimes in Africa created both administrative bureaucracies and colonial companies to exploit the vast natural resources of the continent. A workforce was created made up of the best African brains and trained in western management principles and practices to supply energies for the colonial establishments. "These trained and elevated brains comprised the pioneer group of foreign-loyalist African managers who make up today's African management" (Eze, 1995, pp. 137). The colonial training has not created the salubrious conditions for nurturing African indigenous management practices. Rather, "the colonial training is psychologically emasculating in terms of self-and national identity" (Eze, 1995, pp. 137). The blanket application of those principles and/or the "unmodified transplantation of those practices which are being utilized in the industrialized countries" (Deihl, 1984, pp. 247) has not in any way helped in the progress of developing indigenous African management theories and practices. There was an erosion of African management thought system. Africans, for example, have been skilful managers have a systematic approach based on historical and practical experience to move from the real to the ideal (Osuntokun, 2001).

Any management education programme that facilitates the entrenchment of western management theories and practices in Africa is not desirable. The desire training "must enable the African manager to transform imported theories and concepts into acceptable cultural norms which can then be applied to management practices in Africa" (Fashoyin, 2005, pp. 45). This can further create the opportunity for the development of indigenous African management principles and practices, which will recognize and accommodate our cultural social, political and environmental factors. 
This paper presents the thesis that there is extant knowledge of African management practices and philosophy, which apparently western scholarship deprecates and in its stead, imposes on the continent foreign, western management principles, theories and practices. The challenges of developing indigenous theories and the obvious consequences of this transfer of management knowledge to Africa are discussed. he paper finally advocates an agenda for developing indigenous African management theories and practices that will help advance the course of development in the continent.

\section{Extant knowledge of management in Africa}

Management as a human responsibility and a process that drives economic development and activities is as old as human civilization or history. Africa as part of the global community has existed in her own unique ways and unique cultures and managed the environment subsistently throughout history. The quiet of this environment was extensively disrupted in the $19^{\text {th }}$ century when the Europeans scrambled for and partitioned Africa. This marked the beginning of colonialism in Africa where the people's thought processes and cultures were altered through western "civilization" influences. African management thought was a major culprit of these western influences.

Management literature, which bourgeoned in the west paid scant attention to African civilization, which was no doubt driven by African management prowess. A few of the western textbooks that discussed management history acknowledge the great pyramids in Egypt as depicting early outstanding management activities in Africa. Griffin (2005) notes that: "The practice of management can be traced back thousands of years. The Egyptians used the management functions of planning, organizing and controlling when they constructed the pyramids" (pp. 42). These great pyramids, which were built in 2900B.C. are a classic example of management and co-ordination. It is interesting to note that one pyramid required 100,000 men, working for 20 years, covering 13 acres, using 2.3 million blocks, each weighing an average of 2.5 tons. In fact, an even more astonishing description of Egyptian management prowess is presented by George (1968):

"The building of the pyramids with a technology that would be considered primitive by modern standards, affords us testimony of the managerial and organizational abilities of ancient Egypt ... The managerial planning of where the stone were to be quarried, when, what size, and how they were to be transported required the practice of what today might well be called long-range planning. By using masses of labour the Egyptians were able to accomplish tasks that astonish us. While their system of organization may appear unwieldy, cumbersome, and even wasteful, they actually had no reasons to economize on labour since more peasants, mercenaries, and slaves were always available simply for the asking ... We find also that the Egyptians were aware of sound managerial practices and principles. They understood and appreciated, for example managerial authority and responsibility, and they recognized the value of pooling out job descriptions in detail” (pp. 4-5).

Unfortunately, despite the acknowledgement of the existence of such high-level management skills in Africa, management as practiced in Egypt was tagged "pre-scientific", a connotation of uncivilized management practice. Even though the Egyptian management accomplishments were significant and remembered today, "they provided limited information about how to actually manage" according to Bartol and Martin (1991, pp. 41). The authors went further to distinguish between management practice and management knowledge by stating: "Thus there is a major difference between practicing management well and adding to knowledge about the field of management so that others also can learn to manage" (Bartol and Martin, 1991, pp. 41).

Arguments of this nature fail to recognize the fact that both management practice and management knowledge are not mutually exclusive, and they are required as they provide necessary conditions for nurturing well-grounded management knowledge in our society today. The astonishing Egyptian management practice is a strong and evident system that would have served as a precursor to the evolution and development of indigenous African management theory and practices, if allowed to grow organically without interference from the western management theories.

Formal treatment of the history of management theories and practices among western scholars are wont to trace their provenance to classical theories and scientific management theory or Taylorism (eg. Bartol and Martin, 1991; Bateman and Zeithaml, 1993; Wren, 1994; Kreitner, 1995; Griffin, 2005; Payne, Youngcourt and Watrous, 2006; Hartley, 2006; and Yoo, Lemak and Choi, 2006). These textbooks and publications make no reference to other great ancient civilizations in Africa like Timbuktu, Songhai, Empire of Mali, and Mapungunbwe (Diop, 1987). The composite effect of colonialism and the disparagement of scholarship in management is the denial of African management system, and the continuing subjugation of African management to western management theories and practices.

\section{Understanding the basic concepts in management: principles, theories and practices}

The identification of extant knowledge of management in Africa unequivocally presents sound conditions for the nurturing of management principles, theories and practices, similar to those developed in the United States of America and Europe. The early management activities in Africa were no doubt based on sound principles, which serve the 
foundation for management theories and practices. These basic concepts in management are presented here in the context of developing indigenous African management philosophy.

\subsection{Management principles}

Building a case for African management theories and practices requires one to understand the principles. The principles of management enhance the individual's understanding of what management entails, and also prepares him for the task of analyzing management issues and appreciating their values in society. Principles in management are considered as fundamental truths existing at a given time, and which explain the relationships that exist between two or more sets of variables. Principles are intended to guide thoughts and actions. They are developed from experience acquired through our interaction with the environment in the normal course of working, and carrying out responsibilities in organizational setting.

There are several of these principles of management in western management literature (e.g. Fayol's (1949) fourteen principles of management). The African situation is rather unfortunate since colonialism did not permit the nurturing of indigenous management principles. If these principles were developed, they would have furnished the framework for theorizing in management, within the African context.

The benefits of developing African management principles would be the promotion of research in management. The principles would also help in the attainment of social objectives (Jaja \& Zep-Obipi, 1992). Through the application of principles, the manager co-ordinates the efforts of individuals thereby, reaching the social attainment by summation of the various individual objectives. Principles facilitate management analysis and set the benchmark for training of managers.

Osuala(2000) notes the value of management principles in helping mangers make more accurate decisions, since principles are developed from experience and can be applied. Principles enable people pass information from one generation to the next, and thus avoiding waste of re-inventing the wheel.

\subsection{Management theories}

In its simplest conceptualization, a theory is a systematic grouping of related principles. Management theory therefore serves as a means of classifying pertinent management knowledge. According to Nwachukwu (1992), management theory "is a synthesis of the concepts and principles of management. Management theory attempts to present in a concerted manner those facts about human behaviour in organization" (pp. 6-7). Management theory is scientific in nature relying on observation of events, and analysis of facts to generate hypotheses. A hypothesis represents a general statement of logical or systematic relationship embracing a set of observations. Tested and validated hypotheses are called principles.

Management theory increases managerial efficiency by providing the guidelines to help the managers solve problems in the organization. The theory also helps in crystallizing the nature of management - in terms of analyzing management job and the training of managers. Management theory formulation brings about improvement in research and management practice, leading logically to the attainment of social goals and human development. Porth and Mccall (2001) note that management theories emphasize the importance of an organization's ability to acquire and leverage knowledge that produces meaningful change and innovation.

A related concept to management theory that needs clarification for our purpose is organization theory. Organization theory as a discipline studies the structure and design of organization. It explains, "how organizations are actually designed and suggests the appropriate structural design to improve organizational effectiveness" (Robbins, 1983, pp. 7). Organization theory is therefore the study of the structure and functioning of organizations and behaviour of social groups and individuals within them (Pugh, 1966). The central concern here is with people who are aggregated into departments and organizations - both recognizing differences in structure and behavioural differences.

Organization theory as a way thinking about organization is different from management theory. Organization theory is considered as a set of variables describing the parameters of organization. It attempts to predict the effect of certain structural arrangement on performance and behaviour (Rao \& Narayana, 1998). On the other hand, management theory is interested in facts and sound principles, which prescribe what to do to achieve desired outcome in the organization (Daft, 1986). Management theory is therefore related to management practice.

\subsection{Management practice}

Management theory provides the basis for management practice, and the practice in turn helps to reinforce the development of management theory. Management practice therefore involves the translation of existing management knowledge and theories into action that will result in the achievement of the dual goals of organizational efficiency and effectiveness. Management practitioners and professionals are in the vanguard of management practice, and their practice provides opportunity for reviewing existing management theories and even developing new ones. 
Management theorists and practitioners reinforce one another and are in a continuous process of interaction. The knowledge of both is required to improve our understanding of management in society.

The basic concepts in management as presented above have not been properly developed as well as received adequate attention in African management literature. The influences of colonialism and western management education, theories and practices have a telling effect on their development in Africa. The extant knowledge of management practices and activities in Africa were not allowed to evolve and develop as indigenous African management theories and practices. The implications of this western management transfer are discussed in the following section.

\section{Transferability of management and implications for Africa}

As already pointed out, a major component of colonialism in the African continent is the transfer of western management theories and practices, and education to the autochthonous population of Africa. This was intended to expediently create a pool of qualified labour force to serve the colonial administration and bureaucracy and its diverse interests - and logically leading to economic development. In fact, "the transfer of foreign management knowledge and practices was thus regarded as an essential ingredient of the modernization process" (Usdiken, 1996, pp. 35). This is in adumbration or tandem with Guillen's (1994) proposition that economic backwardness leads to a stronger tendency to import ideas from more advanced countries as well as to imitate them. The general impression often held about Africa is that of a continent suffering from varying degrees of mis-management (e.g. De Sardan, 1999), poor management (e.g. Kiggundu, 1989), inappropriate management (Dia, 1996; Iguisi, 1997), and under management (Drucker, 1974). The widespread belief is that managerial inefficiencies, which retarded economic growth in Africa were essentially due to lack of qualified managers (Safavi, 1981; Kiggundu, 1991; Eze, 1995; and Waiguchu, Tiagha and Mwaura, 1999). The emphasis was then shifted to western management education to produce the qualified managers to service both the public and private sectors of the economy. Currently, there is widespread provision of technical assistance in the managerial area in the "form of the creation of educational institutions whose objectives are the training of indigenous individuals in western management principles and techniques" (Deihl, 1984, pp. 247).

The universalization of management education and principles has affected the evolution of indigenous African management theories and practices, which would have recognized cultural inertia. Culture, is considered as that complex whole which includes knowledge, beliefs, art, law, morals, custom, and any other capabilities and habits that the individual acquires as a member of society. Culture impacts on management practices. Studies have shown that the practice of management is heavily influenced by the traditions, values and habits of a people as well as their political, economic and social contexts (Oshagbemi, 1984; Thomas \& Schonken, 1998; Edoho, 2001; Horwitz, 2002; Jackson, 2004; and Fashoyin, 2005).

The issues of colonialism and colonial mentality are worth further emphasis. The domination of the people by the colonialists has left a strong mark of dependence on the Africans. Though the continent is independent now, our thinking, mode of reasoning, educational system, language are still tied to the colonial influence. This colonial garment, which we have not been able to throw away has in fact, affected our growth in every facet of life. It has affected our being able to develop purely indigenous management principles and theories as we rely solely on the legacies of the colonialists. "The mentality, which we imbibed from the colonial masters, has affected our thought process and social life. It has also affected the culture of our people who have thrown their culture to the winds in preference to the western culture" (Inyang, 2007, pp. 153).

The disruptive effect of the importation of western management theories and education and the resultant clash with African management thought and practices is captured by Nzelibe (1986) thus: "Development of the principles of management was marred, however, by contact with the western world, contact marked by decades of economic exploitation, social oppression and the importation of scientific management, all of which have left acute problems for management today" (pp. 153).

For Kiggundu (1991) colonialism was used as an instrument for destroying local institutions and management practices which were replaced with western administrative structures considered superior to those of the Africans. In effect, indigenous African managerial perspectives were either jettisoned or undervalued (Afro-Centre Alliance, 2001).

Another area where colonialism and western scientific management scholarship impact on Africans is in the representation and portrayal of African leadership and management in organization studies literature of the west. Nkomo (2006) in an extensive leadership theory and management review identifies the problems of representation and identity, where African leadership and management is portrayed subserviently to that of the west. The use of western benchmarks in the evaluation of African leadership and management led to the conclusion that Africa's stunted growth or underdevelopment was essentially due to poor leadership and management, and that the application of western leadership and management theories was the needed panacea to the complex social, economic and political problems of the continent. 
The African educational system has also come under the heavy influence of colonialism. Across the continent, African business schools and management faculties in the universities and other tertiary institutions have not found it expedient to completely review the colonial business curricular, several years after independence. The preponderance of foreign course contents, literature, models, principles, theories, etc have not in any way helped in the development of indigenous African management theories and management practices.

The specific, sad commentary noted here about Nigeria is, in fact, a depiction across the countries of Africa. In his foreword to Ejiofor's (1987) Management in Nigeria: theories and issues, Udo Udo-Aka, a renowned management scholar, draws attention to the urgent need to develop indigenous management principles and concepts to help handle our peculiar problems. He writes in the foreword:

"Nigerian management experts have the great and necessary challenge of evolving management principles and styles which are tailored to meet the needs of our environment. Gone are the days when our schools curricular were dominated by only foreign principles, concepts and background. Our urgent need now is to use that experience to develop the type of curricular that would take cognizance of the peculiarities of our environment" (Ejiofor, 1987, pp. v).

Ejiofor in his work re-echoed this sentiments. Sadly enough, several years after these sentiments were expressed no significant change has been noticed in the orientation and practice of management in Nigeria. There is no obvious change in paradigm as much of our management theories; principles and practices are still western-oriented. Our management curricular in schools has not changed. According to Inyang (2007): "This has impacted seriously on the state of management research, thereby slowing the pace of management development and management education in Nigeria. We need to improve on our management research and develop Nigerian models, which will assist us in tackling or addressing the problems confronting management practice in the country" (pp. 154). By extension, this point is applicable to the entire continent, which is in need of sound management research and education that should evolve organically from Africa's indigenous management thought, reflecting its social milieu and culture.

Another implication of this colonial development and management transfer in Africa is the introduction of the concept of wage employment. Wage employment was a novelty in African countries as economic activities were centered around the family. There was no need for external recruitment of labour. "The only thing akin to recruitment was communal exchange of labour, and of course, there was no cash nexus involved, that is, economic relations were not moderated by exchange of labour for payment of monetary rewards" (Inyang and Akpama, 2002, pp. 15). Eze (1995) notes that during the pre-colonial era, "there was no organizational paid work or employment under the modern organizational structural management; rather, there were family work, community work, and kingdom work" (pp.134-135). The advent of the Europeans and the attendant commercial activities gradually altered this picture. Wage employment became the order of the day in both the public and private sectors of the economy. For services to be obtained and to meet the demands of society - luxuries and taxation - introduced by the colonial administrators, the people embraced wage employment.

This strange development disrupted the communal life of Africans, and who, quite grudgingly accepted the new mode of economic activity. Writing about the African industrial man, Ahiauzu (1999) argues the fact "that wage employment in African communities did not evolve from the traditional mode of work organization, but was introduced to the Africans by the colonial administrators, in a manner that was uncomfortable to the early African workers, has created a dysfunctional impression towards wage-employment among average Africans"(pp. 2). The unenthusiastic response of the African worker toward wage employment tends to affect his attitude and work behaviour in the strange industrial organization he finds himself. This has often led to the unjustified stigmatization of the African worker variously as lazy (Dumont, 1960), lacking in motivation (Kiggundu, 1988 and Blunt and Jones, 1991), and low commitment and loyalty to the organization (Jones, 1986). Ahiauzu (1999) notes that "African managers very often compare the performance of their workers with that of workers in advanced industrial countries, and very easily condemn the African work as lazy, without giving thought to the fact that African workers have a history, which is quite different from that of the industrial societies"(pp. 2-3). Writing in the same vein, Abudu (1986) states that: "This picture of a lazy, leisure-loving African does not stand rigorous examination. The flourishing agriculture, commerce, and industry of pre-colonial Africa belie the notion of the lazy African ... Others have spoken eloquently of the industriousness not the laziness, of Africans. If African performance was different in industry, then an explanation for that difference must be sought" (pp. 24).

The African worker has two worlds: the world of work and the world of home and community. Many writers often overlooked this dual existence with the African worker and his work behaviour. There is need for a better understanding of these issues and to reconcile the differences between life at the work place and life at home and community. The work place is seen as an impersonal system where the worker has no locus of control, while at home and community, the worker sees himself in a humanistic locus where people attach human values to all forms of community interactions and actions. The existing tensions must be reconciled and according to Jackson (2004), a cross-cultural approach is most appropriate in this task. 


\section{The Challenges or difficulties of developing indigenous management theories}

There are several difficulties that are confronting management scholars in developing indigenous African management theories to serve the needs of the continent. Some of these factors, apart from colonialism and western management transfer are:

\subsection{Lack of research facilities}

The governments in Africa have not been able to play their roles by providing research facilities and grants to encourage both basic and applied researches. Most researches have been killed because the originator or researcher did not come from a favoured tribe. Many other researchers have been frustrated by bureaucratic bottlenecks. The private sector too, has not contributed significantly to research efforts in Africa.

\subsection{Intra cultural differences}

"Africa has a greater degree of ethnic, cultural and linguistic pluralism than other continents" (Ogundele, 2006, pp. 238). These differences have made it difficult in having a common idea or front in the area of development of a consistent and acceptable management practice. Apart from religious differences which have also affected the development of management thought, the power struggle between one tribe and the other has affected the acceptability of a culturally bound theory of management over the other. Ethnicity, which can also cause divisiveness among ethnic groups and some people receiving political patronage from the authority, affects the process of developing management theory.

\subsection{Inability of our managers to document their experiences}

Many of our managers apart from not realizing that they are veritable sources of information to the search for indigenous management theory find it difficult to document their experiences. According to (Jaja and Zeb-Opibi, 1999) "The managers themselves did nothing to encourage the development of the management principles and theory. Their major interest was on quick service and money. To achieve that end, the areas of their greatest emphasis were technical know-how or technology, cost and the balance sheet. Through ignorance no inquiry was made into proper and adequate administrative functions and ideal leadership styles" (pp. 16).

\subsection{The relative newness of management as a discipline in our academic institutions}

The relative newness of the study of management in our universities has affected its acceptability, credibility and relevance in our system. Management as it were has not evolved as a local curriculum but a curriculum wholly transferred from foreign university programmes or brochures. The study of management has suffered from lack of indigenous literature that would propagate African management rather than the management theories and practices of the west.

The above challenges or difficulties are, however, not insurmountable as many African scholars are beginning to advocate the evolution and development of indigenous African management theories and practices. This advocacy is presented in the next section.

\section{Evolving and developing African management philosophy}

The legion of problems associated with colonialism and the international transfer of western management theories to Africa has recently, rekindled interest among African scholars to search for and propagate the concept of African management philosophy. This is an attempt to develop indigenous management knowledge and practices, which are rooted in the African culture, value system and beliefs, and to use this management knowledge to run organizations efficiently and effectively. According to Edoho (2001), African management philosophy is:

"The practical way of thinking about how to effectively run organizations - be they in the public or private sectors - on the basis of African ideas and in terms of how social and economic life is actually experienced in the region. Such thinking must be necessarily interwoven with the daily existence and experience in Africa and its contextual reality" (pp. 74).

As noted earlier, the building of the Egyptian pyramids and African civilizations reflected in the Songhai and Mali Empires, Timbuktu, etc have shown unequivocally the African management prowess. These early management activities in the continent must be recognized, developed and integrated into the global management literature. The establishment and institutionalization of the indigenous African management systems is the surest way to enhance African development - economically, politically, and socially (Mbigi 1997; Blunt and Jones, 1997; Kamocho, 2000; Mangaliso, 2001; Anyansi-Archibong, 2001; Ngambi, 2004; and Mbigi 2005).

A few African scholars of note have started the advocacy for indigenous African management philosophy that would serve the need of the African continent. In South Africa for example, there is an emerging philosophical thought system derived from African culture, beliefs, values and behaviours known as Ubuntu, (a Bantu word meaning, broadly, sharing and community). Mangaliso (2001) defines Ubuntu as "humaneness - a pervasive spirit of caring and community, harmony and hospitality, respect and responsiveness - that individuals and groups display for one another. 
Ubuntu is the foundation for the basic values that manifest themselves in the ways African people think and behave towards each other and everyone else they encounter"(pp. 24). Ubuntu philosophy according to (Poovan, du Toit and Engelbrecht, 2006) allows managers to tap into the familiar African values to build and reinforce teams effectiveness by:

(i) pooling resources for survival - maintaining productivity and effectiveness depends on shared values and individual contribution: encourage focus on communal (vs differences) with reliance to minimize threat to survival through conflict;

(ii) engineering unified situations - the spirit of solidarity, that is, mutual regard among members and individual adhesion to the group; create situations defined by 'group' behaviours - sit together, focus, on each other, co-ordinate behaviour;

(iii) enhancing social oneness and participation - set up informal opportunities based on traditional 'pal abre' - central village location for gatherings, activities, mediation, decisions, events and rituals.

Ubuntu is therefore considered as an important value of African culture that can form the foundation of African management philosophy that is in tune with the peoples of Africa. It is argued by its proponents that Ubuntu, adopted as a system of management practice for competitive advantage has universal appeal beyond the shores of the continent (Mbigi, 2005; Mangaliso, 2001). Mangaliso (2001) points out that:

"Incorporating Ubuntu principles in management hold the promise of superior approaches to managing organizations. Organizations infused with humanness, a pervasive spirit of caring and community, harmony and hospitality, respect and responsiveness will enjoy more sustainable competitive advantage" (pp. 32).

Therefore, Ubuntu as a management system emphasizes teamwork, attention to relationships, mutual respect and empathy between leader and followers, and participative decision-making. These are very fundamental principles of management, which hold promise for improving organization activities and functioning in Africa.

Beyond Ubuntu, Eze (1995) in his critical thesis advocates the "new management techniques, which will serve as the basis for developing African management philosophy, to enhance the efficient and effective management of African resources. The fifteen 'techniques', which he identifies, are summarized below to illustrate the issues of management in Africa:

\subsection{Management by self-revolution (MBSR.)}

This involves a critical examination of the weakness of the black race in order to develop in Africans the qualities of self-acceptance, self-knowledge, self-trust, self-pride, self-protection and self-reliance, so that the African will be free from foreign manipulation and become independent, inventive self.

\subsection{Management by ethnic-groups integration (MBEI)}

This would be achieved through workshops, to break down ethnic differences, hostilities and prejudices, and to narrow the workers' social distances by forging new cultural elements at national and organizational levels. Without ethnic integration, national unity and stability, successful adoption of management may not be feasible.

\subsection{Management by attitude change (MBAC)}

Again, this would be achieved through workshops in order to develop a more positive attitude and the willingness and determination to change.

\subsection{Management by patriotism (MBP)}

This involves instilling a patriotic pride and esteem in the workforce through series of orientation activities, laboratory exercises, and successful leadership acts.

\subsection{Management by incentive conversion (MBIC)}

In this case workshops are designed to re-orient the African workers away from spiritual-world incentives to material world incentives; away from religious-social motives to scientific and factual goals.

\subsection{Management by non-corruption (MBNC)}

The attitudinal change programmes aimed at changing African managers' bribery and corruption practices by re-orienting to corporate and national goals. Corruption is antithetical to management.

\subsection{Management by impartiality and meritocracy (MBIM)}

This is to counter autocratic management and inculcate fairness, equity and recognition in management practices through impartiality in personnel matters. 


\subsection{Management by accountability (MBA)}

This means encouraging managers to be accountable.

6.9 Management by performance appraisal (MBPA)

This involves using objective methods of appraisal.

6.10 Management by free-zone (MBFZ)

This is to encourage the free transfer of indigenous knowledge by creating foreign, expatriate and multinational free zones for African mangers to act themselves, engage in trial and error ventures and practice creative and innovative management. He suggests that other nations like Japan, Korea, Taiwan and India have applied this, and this could be applied in Africa.

\subsection{Management by risk-taking (MBRT)}

To overcome one of the main sources of Africa's underdevelopment, which is unwillingness to take risk, African managers must be trained to develop risk-taking attitudes, which are crucial to effective management transfer. This is related to the activity of creating foreign-free zones.

\subsection{Management by research and development (MBRD)}

This is to counter the reluctance of multinational companies in Africa to establish R \& D departments. Indigenous talents can be encouraged and developed by developing capabilities for continuous discoveries, innovations, transformations and invention in African managers.

\subsection{Management by basic revolutions (MBR)}

These basic revolutions should be aimed at the self, psychological, nationalistic, language, cultural, agricultural and educational aspects. These revolutions are necessary to prevent another "partition of Africa" by foreign creditors and international financial institutions, and to bring about an effective African management.

\subsection{Management by planned adaptation (MBPA)}

This is an encompassing management device by, which modern management can be transferred. To be successfully in this exercise, all the above management techniques must be systematically applied and effected in black African countries.

\subsection{Management by human relations (MBHR)}

This technique is to overcome the authoritarian management system imposed by the colonial regimes and multinational companies in Africa. MBHR will develop a more human relationship-based management philosophy that reflects patriotism, nationalism, equal participation, full delegation, human rights, belongingness, ownership, and humanness (pp. 168-175).

The above approach by Eze (1995) is a critical attempt aimed at giving indigenous African management self-confidence to reflect national and indigenous interest, rather than the management principles and practices of the multinational companies and western interests. The common thread that is obvious from the above scholarly advocacy of Ubuntu and the "new management techniques" that will suite the aspirations and developmental needs of Africa, is the humanistic, communalistic and participatory management practices, accommodating African cultural inertia and its social milieu. This embryonic African management philosophy holds lots of promises for the continent if the different strands are effectively nurtured and integrated to provide an alternative to foreign models and management theories, which are apparently unsuitable to the African countries. A study of a diverse South African work force found that imported European and US management practices had limited success; whereas a leadership model that considered cultural differences and emphasized Afro-centric values improved overall performance (British Council Management Express, 2007).

African scholars of management have the onerous responsibility of developing their research skills, to enhance the proper articulation of African management knowledge and practices, toward evolving a coherent indigenous management theory. The emphasis is on the need to develop local concepts and theories of management that are in line with our peculiar situations or circumstances and that will be most effective in achieving our development goals. Eze (1995), in his critical thesis asserts that:

"The recommended fifteen management techniques are considered the most effective methods of achieving adequate preparation of the African management soil and successful adaptation and transfer of modern management. Whatever the form of management that will be transferred, the national management considered most relevant to black African development is the one that is inward-looking, patriotic, nationalistic, revolutionary, adaptive, creative and productive"(pp. 175-176). 
The evolution of African management philosophy has a patriotic flavour, providing the tonic for African cultural renaissance and a reinvention of the African management prowess, astonishingly demonstrated in our early civilizations. The governments in Africa and the private sector should step up efforts by way of releasing funds and making adequate their budgetary provisions for funding research works that bear on management activities. This will serve a major contribution to the development of indigenous African management philosophy.

\section{Conclusion}

Colonialism has enduring impact in the continent of Africa. Traditional economic relationships were completely altered, and replaced with the western economic system, which was essentially cash nexus in nature. Colonial administrative structures were created and imposed on the people, and this in no small way truncated the development of indigenous African administrative system, which apparently, had been accountable for the building of the continent's early civilizations of Egypt and others.

African management thoughts and practices, which under lied these early civilizations of Africa were seriously affected by colonialism and equally devalued and deprecated by western scholarship. This is the bane of African management development. The dominance of western management theories and practices, which are apparently considered as drivers of economic development, have seriously affected the evolution of indigenous African management. There are legions of problems associated with the unwholesome transfer of western management models and theories to Africa. Unfortunately, these theories, which failed to recognize cultural inertia, have not provided the panacea for the overall development of the continent, and neither are the theories suitable for application in our Africa's peculiar circumstances.

The evolution of indigenous African management philosophy is therefore considered as a sine qua non for the development of Africa. This philosophy is rooted in African culture, value system and beliefs, and the derived management knowledge will help the African organizations function more efficiently and effectively. The Ubuntu management system and the "new management techniques" as advocated by African management scholars, set the revolutionary agenda for evolving an indigenous African management philosophy that will emphasize our cultural traits of humanness, communalism, and participatory decision-making in organizational life. African governments and the private sector must support the development of African management philosophy through creating an enabling environment for management research and the provision of adequate research funds or grants.

\section{Acknowledgement}

This paper was presented at the International Conference on Business and Information BAI2008 organized by Academy of Taiwan Information Systems Research, College of Business, National Tapei University and sponsored by Shih-Chien University and Hanyang University, held at Marriott Hotel, Seoul, South Korea, on 7-9 July 2008.

\section{References}

Abudu, F. (1986). Work attitudes of Africans, with special reference to Nigeria. International Studies of Management and Organization, 16 (2):17-36.

Afro-Centric Alliance. (2001). Indigenizing organizational change: localization in Tanzania and Malawi. Journal of Managerial Psychology, 16 (1):59-78.

Ahiauzu, A. (1999). The African industrial man. Port Harcourt, Nigeria: Cimrat Publications.

Anyansi-Archibong, C. B. (2001). Toward an African-oriented management theory. In F. M. Edoho (Ed.), Management Challenges for Africa in the Twenty-first Century: theoretical and applied perspectives (pp. 63-72). Westport, CT: Praeger.

Bartol, K.M. \& Martin, D.C. (1991). Management. New York: McGraw-Hill.

Bateman, T.S., \& Zeithaml, C. P. (1993). Management: function and strategy $\left(2^{\text {nd }}\right.$ Edition). Burr Ridge, Illinois: Irwin.

Blunt, P. \& Jones, M. L. (1992). Managing organizations in Africa. Berlin: Walter de Gruyter.

Blunt, P. \& Jones, M. L. (1997). Exploring the limits of western leadership theory in East Asia and Africa. Personnel Review, 26, 6-23.

British Council Management Express. (2007). Globalization and management practices in Africa. [Online] Available: www.britishcouncil.org/nigeria(January 10, 2008).

Daft, R. L. (1986). Organizational theory and design ( $2^{\text {nd }}$ Ed.), New York: McGraw-Hill.

Deihl, L. (1984). Management theory versus practice in developing countries. In P.N.O. Ejiofor \& V.A. Aniagoh (Eds.), Managing the Nigerian Worker (pp. 247-25). Ibadan: Longman Nig. Ltd.

De Sardan, J. P. O. (1999). A moral economy of corruption in Africa? The Journal of Modern African Studies, 37 (1):25-52. 
Dia, M. (1996). Africa's management in the 1990s and beyond. Washington, D.C.: World Bank.

Diop, C.A. (1987). Pre-colonial black Africa. Westport, CT: Lawrence Hill \& Company.

Drucker, P. F. (1974). Management: tasks, responsibilities, practices. Oxford: Butterworth-Heinemann.

Dumont, R. (1960). False start in Africa. London: Andre Deutsh.

Edoho, F.M. (2001). (Ed.) Management challenges for Africa in the twenty-first century: theoretical and applied perspectives. Westport, CT: Praeger.

Edoho, F. M. (2001). Management in Africa: the quest for a philosophical framework. In F. M. Edoho (ed.), Management challenges for Africa in the twenty-first century: theoretical and applied perspectives (pp. 73-90). Westport, CT: Praeger.

Ejiofor, P.N.O. (1987). Management in Nigeria: theories and issues ( $2^{\text {nd }}$ edition). Lagos: Africana-FEP Publishers Limited.

Eze, N. (1995). Human resource management in Africa: problems and solutions. Lagos, Nigeria: Zomex Press.

Fashoyin, T. (2005). Management in Africa. Lagos Organization Review, 1(1):43-45. This article was first published in the Regional Encyclopedia of Business and Management: Management in Emerging Countries, (pp. 169-175) edited by Malcolm Warner, 2000, Thomson Learning.

Fayol, H. (1949). General and industrial management. Translated, C. Stones. Marshfield, Mass: Pitman Publishing

Gbadamosi, G. (2003). HRM and the commitment rhetoric: challenges for Africa. Management Decision, 41(3):274-280.

George, C. S. (1968). The history of management thought. Englewood Cliffs. N. J: Prentice-Hall.

Griffin, R. (2005). Management, $8^{\text {th }}$ Edition. Boston: Houghton-Mufflin.

Guillen, M.F. (1994). Models of management. Chicago: University Press.

Hartley, N.T. (2006). Management history: an umbrella model. Journal of Management History, 12 (3):278-292.

Horwitz, F.M. (2002). Whither South African Management? In M. Warner \& P. Joynt (eds), Managing across culture, pp.215-220. London: Thomson Learning.

Iguisi, O. (1997). The Role of Culture In Appropriate Management and Indigenous Development. Proceedings of the First African Seminar on Culture dimensions to appropriate management in Africa. Makere University Kampala, Uganda, December 1995, Paris: UNESCO, 18-46.

Inyang, B. J. (2007). Management theory: principles and practice, $2^{\text {nd }}$ edition: Calabar, Nigeria: Merb Publishers.

Inyang, B. J. \& Akpama, A. M. (2002). Personnel management practice in Nigeria. Calabar, Nigeria: Merb Business Centre.

Jackson, T. (2004). Management and change in Africa: a cross-cultural perspective. New York: Routledge.

Jaja, S. A. \& Zeb-Obipi, I. (1999). Management: elements and theories. Port Harcourt, Nigeria: Pearl Publishers.

Jones, M. L. (1986). Management development: an African focus. Management Education and Development, 17(3):302-16 (and reproduced in International Studies of Management and Organization (1989), 19(1):74-90.

Kamoche, K. (2000). Sociological paradigms and human resources: an African context Aldershot: Ashgate.

Kiggundu, M.N. (1988). Africa. In R. Nath (ed.) Comparative management: a regional view. Cambridge, M.A: Ballinger.

Kiggundu, M.N. (1989). Managing organizations in developing countries. West Harford, CT: Kumarian Press.

Kiggundu, M.N. (1991). The challenge of management development in sub-saharan Africa. Journal of Management Development, 10(6):32-47.

Kreitner, R. (1995). Management. $6^{\text {th }}$ Edition. Bostom: Houghton Miffin Company.

Mangaliso, M.P. (2001). Building competitive advantage from Ubuntu: management lessons from South African. Academy of Management Executive, 153(3):23-23.

Mbigi, L. (1997). Ubuntu: the African dream in management. Pretoria: Knowledge Resources.

Mbigi, L. (2005). The spirit of African leadership. Johannesburg: Knowledge Resources.

Ngambi, H. (2004). African leadership: lessons from the chiefs. In T.A.Meyer \& I. Boninelli (Eds.), Conversations in leadership: South African perspective (pp. 107-132). Johannesburg: Knowledge Resources. 
Nkomo, S. M. (2006). Images of 'African leadership and management' in organization studies: tensions, contradictions and revisions. Inaugural Lecture presented in the University of South Africa, Pretoria, on 7 March 2006. [Online] Available: Isaunisa.uc.za/news/archive/march/vol.1/docs/Inaugural-Stella-Nkomo.Pdf (January 3, 2008)

Nwachukwu, C. C. (1992). Management theory and practice. Onitsha, Nigeria: Africana FEP Publishers Limited.

Nzelibe, C. O. (1986). The evolution of African management thought. International Studies of Management and Organization, 16 (2):6-16.

Ogundele, O. J. K. (2006). Management and organization: theory and behaviour. Lagos, Nigeria: Molofin Nominee.

Oshagbemi, T. A. (1984). The management of culture for effective performance. In P.N.O. Ejiofor \& V.A. Aniagoh. (Eds.), Managing the Nigerian Worker (pp. 253-256). Ibadan: Longman Nig. Ltd.

Osuala, E. C. (2002). Business Management. Onitsha, Nigeria: Cape Publishers International Limited.

Osuntokun, J. (2001). Some thoughts on traditional African idea of management. The Journal of Cultural Studies, 3 (1):99-107.

Payne, S. C., Youngcourt, S. S. \& Watrous, K. M. (2006). Portrayals of F. W. Taylor across textbooks. Journal of Management History, 12 (4):385-407.

Poovan, N., du Toit, M.K. \& Engelbrecht, A.S. (2006). The effect of social value of Ubuntu on team effectiveness. South African Journal of Business Management, 37 (3):219-233.

Porth, S. J., \& Mccall, J. (2001). Contemporary management theories and Catholic social teaching: similarities and differences. Review of Business, 22 (3):8-21.

Pugh, D. S. (1966). Modern organization theory: a psychological and sociological study. Psychological Bulletin, 66 (21):235-251.

Rao, V. S. P. \& Narayana, P. S. (1998). Organization theory and behaviour $2^{\text {nd }}$ Rev. Ed. Delhi: Konark Publishers PVT. LTD.

Robbins, S. P. (1983). Organization theory. New York: Prentice-Hall.

Safavi, F. (1981). A model of management education in Africa. Academy of Management Review, 6 (2):319-331.

Thomas, A. \& Schonken, J. (1998). Culture-specific management movement. South African Journal of Business Management, 29 (2):53-76.

Usdiken, B. (1996). Importing theories of management and organization: the case of Turkish academia. International Studies of Management and Organization, 26(3):33-45.

Waiguchu, J. M., Tiagha, E. \& Mwara, M. (1999). Management and organizations in Africa: a handbook and reference. Westport, CT: Quorum Books.

Wren, D. A. (1994). The evolution of management thought, $\left(4^{\text {th }}\right.$ ed.), New York: Wile.

Yoo, J. W. Lemak, D.J. \& Choi, Y. (2006). Principles of management and competitive strategies: using Fayol to implement Porter. Journal of Management History, 12 (4):352-368. 